\title{
Why Most University-Industry Partnerships Fail to Endure and How to Create Value and Gain Competitive Advantage through Collaboration - A Systematic Review
}

\author{
DOI: 10.12776/QIP.V24I2.1389
}

\author{
Arlindo Marinho, Rui G. Silva, Gilberto Santos \\ Received: 2020-01-20 Accepted: 2020-04-25 Published: 2020-07-31
}

\begin{abstract}
Purpose: The collaborative work between universities and enterprises is increasingly important given the growing competitive environment, transformed by intense global competition, rapid technological change and shorter product life cycles. In this article several case studies are analysed, as well as relevant academic literature, to get an insight concerning the current relationship status between enterprises and universities.
\end{abstract}

Methodology/Approach: The methodology is grounded on the literature review on University-Industry Partnerships, selected from indexed sources, and targeted to case-based experiences where practical feedback is given.

Findings: It is shown that university-industry knowledge transfer contributes significantly to an increase of quality, productivity and economic value of businesses. It is found that the lack of controlling mechanisms and lack of efficient communication paths have a strong negative impact in collaboration. Key collaboration factors that support stronger relationships were compiled and discussed in support of better mitigation strategies.

Research Limitation/implication: The limited availability of case studies reporting on operative improvements introduced by policy changes hinders the effectiveness of the findings.

Originality/Value of paper: The paper analyses the collaboration of the university with industry based on case studies with a focus on value creation and how to gain a competitive advantage through collaboration.

Category: Literature review

Keywords: collaboration; knowledge transfer; competitiveness 


\section{INTRODUCTION}

Collaboration between universities and industry in Europe, presents a heterogeneous landscape. Cooperation enterprise - university is a recent phenomenon and incipient (Unger et al., 2018; Jarábková, Chreneková and Roháčiková, 2019). Companies and universities are different in their organization and cultures and hence technology management perspectives are different. There is still significant room for better and more intense cooperation between universities and businesses, but difficulties remain in terms of trust and understanding of the operation on both sides (Pal'ová, Czaja and Vejačka, 2018; Roud and Vlasova, 2018). Nevertheless, models or theoretical frameworks to understand how customers and other stakeholders are involved with companies in collaborative activities of co-creation of value (Frow et al., 2015) are still poor. Much of the attention in research has recently been placed on case studies of large multinational companies and well-known universities (Edmondson, 2012). Few studies have considered the collaboration between universities, SMEs and non-governmental organizations.

Higher education institutions and companies benefit from working together and collaboration encourages the transfer and sharing of knowledge hence aiding in the creation of long-term partnerships (Guan and Zhao, 2013). In the process of innovation, it is also increasingly highlighted the importance of collaboration between science, information and technology (Rebelo, Santos and Silva, 2015; Wu and Chiu, 2015; Unger et al., 2018) and that, in the advanced industrial economy, there is a strong integration of the activities of science and technology systems (Bravi, Murmura and Santos, 2018). Collaboration is becoming a powerful source of competitive advantage. However, the process of knowledge transfer has some weaknesses particularly with regards to communication and collaboration between universities and companies with influence on their capacity for innovation and hence compromise successful relationships. There are nevertheless key factors present in the determinants of interaction that, identified and properly addressed, will overcome some of the barriers and assist the management of collaboration university - enterprise making it more profitable and thus a source of value for both parties and society in general.

The aim of the paper is hence to explore, identify and discuss the importance of key issues pertaining to the relationship between universities and industry and how to mitigate the effects of neglected factors. The article first addresses the common strategies used in the university-industry relationship highlighting the benefits that can be brought through those partnerships. The next section highlights the role of innovation in getting sustained competitive advantage for industry and why universities are the perfect allies to achieve those goals. The following two sections report on the success of partnerships and highpoint major constraints that undermine the success and future of collaboration between industry and universities. 


\section{METHODOLOGICAL APPROACH}

The methodology is grounded on the literature review on University-Industry Partnerships, selected from indexed sources, and targeted to literature reviews in the field as well as case-based experiences where practical feedback is given. This paper presents a critical review on the key aspects pertaining to the relationship between universities and industry. The approach used in elaborating the article consisted of two steps: (i) identify the central theme of the research, through a general literature search in ScienceDirect, Google Scholar, Springer, Taylor\&Francis and major indexed journals in SCOPUS using the terms "Collaboration", "Knowledge Transfer", "Competitiveness", and "Value Creation", and (ii) select major case studies that dwell on the central topic and sent address the relationship problems. In order to ensure that relevant case studies and reviews on collaboration mechanisms pertaining to the UniversityIndustry relationship were not neglected, relevance was taken into account as well as temporal limitation to the last 10 years, especially between 2014 and 2019, with some exceptions pertaining to historical reports, agreements or governing acts. The most accessed articles in the period were also reviewed to verify and categorize the themes.

\section{COLLABORATION STRATEGIES AND COMPETITIVE ADVANTAGE}

The word collaboration is associated with positive ideas of interaction and convergence of efforts in favour of a particular accomplishment. People who come to collaborate do it in the expectation of achieving, in interaction with others, something that previously did not have. This approach can result in professional development and contributions to improvements in the areas in which they operate. Collaboration is therefore an instrument that promotes the development of people and activities and allegedly also the organizations to which they belong (Reficco et al., 2018). When there is a collaborative relationship responsibility must be balanced and assumed by all stakeholders, regardless of their different functions (Lin, 2017). This process should take into account four aspects: Conceptual convergence, which highlights the importance of having a common understanding of what it means and what it implies to collaborate and agree on the interest to work together for a particular purpose, building a shared vision; Agreement on the definition of objectives, which touches the importance of being defined as a whole leading to a course of actions in which all see themselves and engage; Shared management, highlighting the assumption of responsibility for managing the process; and, finally, the anticipation of individual incomes that should result in benefits for each and for all participants, to the organizations to which they belong and the society, in its relationship with the developed activity and the people involved in it. In collaborative work the will to accomplish together should always be present, thus it implies having confidence in others, valuing their knowledge and experience 
and believe that it is possible to go further together than alone (Un and Rodríguez, 2018). The generation of ideas to solve problems is the currency of the future and should be addressed by well-integrated teams (Edmondson, 2012). Thus, adaptable and talented companies able to manage change and with skills to make the business environment faster and disruptive will be better positioned to address current and future challenges.

Competitive advantage has been viewed according to two dominant theories, one considering a view based on the market, which argues that the structure and competitive dynamics of the industry in which it operates are the main determinants of the company's performance and the vision based on resources that emphasizes the importance of resources that companies use as the main source of competitive advantage (Ghadimi, Ghassemi Toosi and Heavey, 2018). The notion of core competencies is closely related to the vision based on resources, deriving from it also a vision based on knowledge and vision based on capabilities. A recent formulation, the relational view, has received considerable attention and it argues that in the current globalization environment, most companies cannot deal with the rapidly changing competition confined to their own resources and capabilities. The success of contemporary companies is achieved through a sustainable competitive advantage, achieved by their ability to develop a set of core competencies that ensure a better approach to meet the needs of customers compared with its competitors (Eftimoski and Milenkovski, 2012).

\section{COMPETITIVENESS VS. INNOVATION}

Business leaders are faced with increasing competition, with globalization, with technological changes and a new strategic thinking. These factors, in a competitive and dynamic changing environment, should therefore be managed in order to build and sustain a high-performance organization. It is therefore necessary to combine scarce resources to achieve critical mass to boost the introduction of innovation in the market and improve collaboration especially concerning research and innovation activities that determine productivity growth and industrial competitiveness. Innovation has long been considered, given the growing competition, as a form of survival (Smirnova, Rebiazina and Khomich, 2018) and the request for innovation can come from explicit demands of the market or as a result of research and development activities within companies. Innovation is not just a process of creating ideas, but also the result of a complex social interaction, communication and exchange of knowledge.

The generation of innovation within the company involves two elements: resources and the ability to build networks - although innovation is not a sole characteristic of companies that are involved in networks but does happen also in individual companies (Konsti-Laakso, Pihkala and Kraus, 2012), as there is also a positive relationship between growth, innovation and the use of external relations of various types. In fact, the development of innovation requires support 
for research and development and cooperation with other organizations (Jørgensen and Ulhøi, 2010). Hence, the networks represent a possible solution that enables companies, particularly SMEs, to overcome their constraints and promote innovation. The literature also points to the active role of consumers as a value co-creation key component in innovation activities (Liao, $\mathrm{Hu}$ and Ding, 2017). This outlook incorporates new forms of customer engagement (Santos, Murmura and Bravi, 2019), their interaction and integration with the innovation activities of the company (Cui and Wu, 2016; Ferreira Rebelo, Silva and Santos, 2017; Araújo et al., 2019). The key element of this approach relates to the recently-enabled client and connected that leverages new technological developments and attempts to achieve greater involvement and control of the innovations within companies (Orviská et al., 2019; Barbosa, de Oliveira and Santos, 2018).

Knowledge is the ingredient that underpins the competitiveness of regions, countries, sectors and companies. In the global economy the creation of high added value is based on innovation grounded on the ability to create and transform new ideas into new products and processes commercially valued. The health and wealth of societies increasingly depend on its ability to innovate and science and technology appear as a key source of competitive advantage. Linking basic and applied research to the market through technology transfer and marketing mechanisms, including partnerships government - university industry, and capital investment, will constitute the key driver of sustainable competitive advantage and prosperity (Carayannis and Campbell, 2012). The public - media, culture and civil society - uses and applies knowledge and by doing so, is also part of the innovation system, in fact, in a society of knowledge and advanced economy, knowledge flows in all spheres of society. Diverse and heterogeneous culture configurations should help promote creativity, necessary and essential for the creation and production of new knowledge and innovations. This encourages the development of "creative knowledge spaces", i.e., environments, contexts and surrounding areas that have a positive influence on human beings involved in creative work (Resetarits and Resetarits-Tincul, 2012).

An advanced knowledge economy embraces innovation and creativity at the same time and the more mature and advanced it becomes then the more creative it is required to be since more knowledge, innovation and creativity can be absorbed (Dubina, Carayannis and Campbell, 2012; Chi et al., 2018). The creative economy inter-relates creatively technological innovations with social innovations. Also, the competitiveness and superiority of a system of knowledge or the advanced level of development of a knowledge system is highly determined by their ability to adapt to combine and integrate different modes of knowledge and innovation (Carayannis and Campbell, 2012). One major fact is that knowledge is socially constructed and is better supported through collaborations in which participants share knowledge and discuss projects that incorporate characteristics, real world content and use of various sources of information, in teams. This is the most widely supported present approach, 
especially when regarding the use of information technology, and hence collaboration and knowledge transfer are gaining popularity.

\section{COLLABORATION WITH UNIVERSITIES}

Multinational companies have set the example in developing international networks known as "Centres of Excellence" with universities and research institutions and assumes a strategic importance for public administration at two different levels: from a national point of view it contributes to enhance national research and knowledge capital; from a local point of view it promotes the involvement of major economic and academic actors and represent a unique resource to promote a sustainable and durable development in the region. Within this framework, the strategic partnership is a form of organization designed to integrate different tools of intellectual capital, with the focus on specific projects, where each partner brings operational issues and different business cultures. It is believed that European universities can significantly increase their attractiveness since partnerships are a clear priority and also there is a growing number of academics who have worked in companies (Edmondson et al., 2012). Reinforcing this idea, the European Union has recognized the important role higher education institutions play - through education, research and innovation in the transfer of knowledge to society and its vital contribution to the competitiveness of the European economy (Plewa et al., 2013). And yet, when universities form partnerships with industry, often the potential for synergy is frustrated due to communication failures. Although new information and communication technologies makes it easier to access research results, there is still a large gap between the knowledge produced by researchers and the one which is used in practice. The "European paradox" depicts a strong research capacity but lacks the strength to translate this into innovative products (Ranga et al., 2013). The reasons for this gap is attributed mainly to researchers who often have much more interest and devote more time and effort to the production of new knowledge than to their disclosure.

Several authors argue that the key to successful knowledge transfer is an ongoing dialogue process, an accumulation of social networks, hence a strong emphasis should be placed in building strong personal relationships (as opposed to institutional relations), and building trust, a key element in business (Johnston and Huggins, 2016). The collaboration university-company is based on a mental attitude, it is driven by intrinsic and psychological elements (trust, mutual commitment, common objectives) and not by rules or quantifiable elements (Edmondson et al., 2012). The literature suggests as influences facilitators, in creating and maintaining Industry - University relationships, the confidence (Schilke and Cook, 2013), and the existence of collaboration champions, acknowledging the impact they have on technology and learning outcomes. Although cooperation between organizations can be achieved through various mechanisms, it should be highlight the importance of trust as a means to establish 
and maintain the relationship (Huang and Wilkinson, 2014). Trust is a crucial element for effective negotiations, when negotiators trust each other they are more likely to develop a strategy for value creation and problem solving, involving information sharing, needs and help the other party achieve its objectives (de Klerk, 2012). In the context of inter-cooperative arrangements, trust is mutual confidence - no agent should exploit the vulnerabilities of others. It is therefore associated with the "problem" specific risk and is a remedy for its resolution. In the absence of an environment of uncertainty or risk, trust has no meaning. Trusting means travelling with the risk of betting on the uncertain future (Nguyen and Liem, 2013). Trust is built on inter-organizational relationships over time and come to play a greater role in maintaining the relationship (Schilke and Cook, 2013). In summary, trust is the result of behaviour "right", "fair" and "serious" where decisions and morally correct actions are based on ethical principles that recognize and protect the rights and interests of others (Hewitt-Dundas, Gkypali and Roper, 2019).

A successful collaboration does not just happen; it must be carefully planned and nurtured, it is then important to fully understand what makes this collaboration become a success (Rajalo and Vadi, 2017). When new knowledge is created as a result of a collaborative project, the perspectives of the parties are often changed (Bruneel, D'Este and Salter, 2010) - Scholars have an incentive to disseminate the results at the beginning, to improve their reputation in the scientific community and companies, in contrast, have an incentive to postpone disclosure of results, in order to ensure a competitive advantage. Other potential conflicts may arise due to different attitudes about intellectual property rights or differences in language and values that affect communication (Hewitt-Dundas, Gkypali and Roper, 2019). It is important that the motives and objectives of each partner are clearly identified and explained. Moreover, it is also important that all partners have the opportunity to influence decisions that affect the partnership (Anderson, Michael and Peirce, 2012). Removing barriers, however, is not enough: the drivers of the partnership and the presence of obvious benefits, which act as motivators, are also necessary to promote collaboration (Edmondson et al., 2012), building trust among all stakeholders (Piacentini, 2013; Rehák, Šipikal and Lešková, 2019).

\section{MAJOR CONSTRAINS IN COLLABORATION STRATEGIES}

From the given review there are some key aspects that should be addressed by universities and enterprises when engaging in a relationship in order to gain a competitive advantage through collaboration and enable future collaborations to flourish. Below are presented recommendations that summarize findings pertaining to the sustainable development of a University - Enterprise partnership. Table 1 presents a summary of major aspects neglected by most partnerships, corroborated by numerous authors that often lead to unsuccessful collaborations. These aspects are next discussed and analysed from a constructive 
perspective highlighting the advantages and contributions to healthier and fruitful partnerships.

Table 1 - Neglected Collaboration Factors in Partnerships

\begin{tabular}{|c|c|}
\hline Collaboration Factor & Source \\
\hline Partner Selection & $\begin{array}{l}\text { Giesecke (2012), Ranga and Etzkowitz (2013), Bunduchi (2013), Thune } \\
\text { and Gulbrandsen (2014), Le Roy, Robert and Lasch (2016), Mindruta, } \\
\text { Moeen and Agarwal (2016), Johnston and Huggins (2016), Criscuolo et al. } \\
\text { (2017), Yoon et al. (2017), Ankrah and Al-Tabbaa (2017), Hartman and } \\
\text { Dhanda (2018), Frølund, Murray and Riedel (2018), Reichert (2019) }\end{array}$ \\
\hline $\begin{array}{l}\text { Collaboration } \\
\text { Management }\end{array}$ & $\begin{array}{l}\text { Giesecke (2012), Ranga and Etzkowitz (2013), Ankrah and Omar (2015), } \\
\text { Sum Chau, Mark and Serbanica (2016), Grimpe, Goel and Göktepe-Hultén } \\
\text { (2017), Jonkers et al. (2018), Hartman and Dhanda (2018), Merritt and } \\
\text { Kelley (2018), Frølund, Murray and Riedel (2018), Reichert (2019) }\end{array}$ \\
\hline Interface Management & $\begin{array}{l}\text { Giesecke (2012), Ranga and Etzkowitz (2013), Plewa et al. (2013), Thune } \\
\text { and Gulbrandsen (2014), Perkmann and Schildt (2015), Yoon et al. (2017), } \\
\text { Ankrah and Al-Tabbaa (2017), Champenois and Etzkowitz (2018), Al- } \\
\text { Tabbaa and Ankrah (2018), Reichert (2019) }\end{array}$ \\
\hline The Use of Champions & $\begin{array}{l}\text { Ranga and Etzkowitz (2013), Plewa et al. (2013), Bstieler, Hemmert and } \\
\text { Barczak (2015), Sum Chau, Gilman and Serbanica (2016), Yoon et al. } \\
\text { (2017), Veles, Carter and Boon (2018), Merritt and Kelley (2018), De } \\
\text { Silva, Howells and Meyer (2018), Reichert (2019) }\end{array}$ \\
\hline Long-term partnership & $\begin{array}{l}\text { Perkmann and Salter (2012), Giesecke (2012), Ranga and Etzkowitz } \\
\text { (2013), Thune and Gulbrandsen (2014), Yoon et al. (2017), Frølund, } \\
\text { Murray and Riedel (2018), Reichert (2019) }\end{array}$ \\
\hline $\begin{array}{l}\text { Shared Vision and } \\
\text { Strategy }\end{array}$ & $\begin{array}{l}\text { Giesecke (2012), Ranga and Etzkowitz (2013), Thune and Gulbrandsen } \\
\text { (2014), Bstieler, Hemmert and Barczak (2015), Sum Chau, Gilman and } \\
\text { Serbanica (2016), Yoon et al. (2017), Ankrah and Al-Tabbaa (2017), } \\
\text { Hartman and Dhanda (2018), Frølund, Murray and Riedel (2018), de Wit- } \\
\text { de Vries et al. (2018), Reichert (2019) }\end{array}$ \\
\hline
\end{tabular}

The literature highlights two distinct phases in the development of the collaborative process, namely "partner selection" and "partnership management" which are the key elements to its overall success. In the selection of a partner the necessary conditions for the success of a partnership is to ensure the correspondence between the motivations of companies and strengths of the university. The collaboration history, geographical proximity and technological capabilities are also important factors to consider. In the second phase, managing the partnership assumes relevance since outsourcing of innovation is vulnerable to opportunism on both sides, given the limits of uncertainty and monitoring. Both academics and companies seek partners with complementary objectives and skills, whose evaluation depends on the success of the project. Hence a key linkage must exist to ensure that there is frequent, and ongoing, personal involvement between university researchers and industry managers. Collaborations only work well when they are managed by people who cross 
borders with ease and that have a deep knowledge of the two cultures, thereby the use of Champions.

The first step to a healthy partnership must be given with the identification of main university strengths and the core competencies of the company while aiming to identify promising opportunities for collaboration. It is required a thorough understanding of the three different types of possible partnerships; strategic, operational or transactional, and select the one that best fits both partners. Clearly defined objectives, realistic and mutually agreed are also very important factors in the management of collaborative projects. Without clearly defined goals, projects tend to become too large and beyond their initial limits. Moreover, the importance of the project leader and effective communication should be emphasized in order to continuously balance ambitions and expectations. There is no shortcut to cultivate personal ties that could lead to more creative and promising collaborations. Universities should create opportunities for scholars and researchers from companies and executives with common interests to meet and develop a dialogue. The most fruitful partnerships take time to produce results.

\section{CONCLUSION}

Several studies highlight the importance of universities as providers of significant opportunities for the development of new knowledge, in addition to teaching and research, changing the role of universities in marketing and contributing significantly to innovation. Research findings show, however, that companies typically do not often use university relationships to strengthen and build core competencies given that the cultural and philosophical differences still exist between industry and academia. Universities have a time orientation and goals that are different from industrial companies. In addition, it seems to emerge from literature that companies are apprehensive about the dependence on universities, especially in areas that are crucial to the creation of competitive advantage, even though it is demonstrated that it is a neglected area and can be very useful for companies. There are therefore difficulties that remain in terms of trust and understanding of operations on both sides. Reducing complexity, fostering relationships and introducing effective intermediation, particularly for small businesses, are recommendations that sustain strong, trustworthy relationships between people in business and academia setting the foundations for successful collaboration. Partnerships often fail to properly address the expected outcomes for both parties and hence cause the deterioration of the relationship. The compiled list of key neglected factors highlights the necessity for the prioritization of aspects such as: Partner Selection; Collaboration Management; Interface Management; The Use of Champions; Long-term partnership; and, Shared Vision and Strategy. People are key to making any collaboration work in a productive and lasting way wish is often undermined by poor leadership and negligence concerning the stakeholders' interests. Long-term 
alliances build the human capital necessary for the operation of industryuniversity collaborations and over time a well-managed partnership produces an increasing number of teachers and graduate students who can think and act through cultural division, connecting with the company's major research interests and work harmoniously to define broad and common goals. It is thou required that both companies as well as academia delineate policies to mitigate nefarious effects of the neglected key relationship factors.

\section{REFERENCES}

Al-Tabbaa, O. and Ankrah, S., 2018. Engineered" University-Industry Collaboration: A Social Capital Perspective. European Management Review, [ejournal] 16(3), pp.543-565. DOI: 10.1111/emre.12174.

Anderson, T.S., Michael, E.K. and Peirce, J.J., 2012. Innovative Approaches for Managing Public-Private Academic Partnerships in Big Science and Engineering. Public Organization Review, [e-journal] 12(1), pp.1-22. DOI: 10.1007/s11115010-0142-3.

Ankrah, S. and Al-Tabbaa, O., 2017. Universities - industry collaboration: A systematic review ScienceDirect Universities - industry collaboration: A systematic review. Scandinavian Journal of Management, [e-journal] 31(3), pp.387-408. DOI: 10.1016/j.scaman.2015.02.003.

Ankrah, S. and Omar, A., 2015. Universities-industry collaboration: A systematic review. Scandinavian Journal of Management, [e-journal] 31, pp.387408. DOI: 10.1016/j.scaman.2015.02.003.

Araújo, R., Santos, G., da Costa, J.B., and Sá, J.C., 2019. The quality management system as a driver of organizational culture: An empirical study in the Portuguese textile industry. Quality Innovation Prosperity, [e-journal] 23(1), pp.1-24. DOI: 10.12776/QIP.V23I1.1132.

Barbosa, L.C.F.M., de Oliveira, O.J. and Santos, G., 2018. Proposition for the alignment of the integrated management system (quality, environmental and safety) with the business strategy. International Journal for Quality Research, [ejournal] 12(4), pp. 925-940. DOI: 10.18421/IJQR12.04-09.

Bravi, L., Murmura, F. and Santos, G. 2018. Manufacturing labs: Where new digital technologies help improve life quality International. International Journal for Quality Research, [e-journal] 12(4), pp.957-974. DOI: 10.18421/IJQR12.0411.

Bruneel, J., D'Este, P. and Salter, A., 2010. Investigating the factors that diminish the barriers to university-industry collaboration. Research policy, [ejournal] 39(7), pp.858-868. DOI: 10.1016/j.respol.2010.03.006. 
Bstieler, L., Hemmert, M. and Barczak, G., 2015. Trust formation in universityindustry collaborations in the U.S. biotechnology industry: IP policies, shared governance, and champions. Journal of Product Innovation Management, [ejournal] 32(1), pp.111-121. DOI: 10.1111/jpim.12242.

Bunduchi, R., 2013. Trust, partner selection and innovation outcome in collaborative new product development. Production Planning and Control, [ejournal] 24(2-3), pp.145-157. DOI: 10.1080/09537287.2011.647868.

Carayannis, E.G. and Campbell, D.F.J., 2012. Mode 3 Knowledge Production in Quadruple Helix Innovation Systems. In: E.G. Carayannis and D.F.J. Campbell, eds. 2012. Mode 3 Knowledge Production in Quadruple Helix Innovation Systems: 21st-Century Democracy, Innovation, and Entrepreneurship for Development. New York: Springer. pp.1-63. DOI: 10.1007/978-1-4614-2062$0 \_1$.

Criscuolo, P., Dahlander, L., Grohsjean, T. and Salter, A., 2017. Evaluating novelty: The role of panels in the selection of R\&D PROJECTS. Academy of Management Journal, [e-journal] 60(2), pp.433-460. DOI: 10.5465/amj.2014.0861.

Cui, A. and Wu, F., 2016. Utilizing customer knowledge in innovation: antecedents and impact of customer involvement on new product performance', Journal of the academy of marketing science, [e-journal] 44, pp.516-538. DOI: 10.1007/s11747-015-0433-x.

de Klerk, S., 2012. Establishing and developing business networks: The importance of trust. African Journal of Business Management, [e-journal] 6(18), pp.5845-5856. DOI: 10.5897/AJBM11.2637.

De Silva, M., Howells, J. and Meyer, M., 2018. Innovation intermediaries and collaboration: Knowledge-based practices and internal value creation. Research Policy, [e-journal] 47(1), pp.70-87. DOI: 10.1016/J.RESPOL.2017.09.011.

de Wit-de Vries, E., Dolfsma, W.A., van der Windt, H.J. and Gerkema, M.P., 2018. Knowledge transfer in university-industry research partnerships: a review. The Journal of Technology Transfer, 44, pp.1236-1255. DOI: 10.1007/s10961018-9660-X.

Dubina, I., Carayannis, E. and Campbell, D., 2012. Creativity economy and a crisis of the economy? Coevolution of knowledge, innovation, and creativity, and of the knowledge economy and knowledge society. Journal of the Knowledge, [e-journal] 3(1), pp.1-24. DOI: 10.1007/s13132-011-0042-y.

Edmondson, A.C., 2012. Teamwork on the fly. Harvard Business Review. [online] Available at: <https://hbr.org/2012/04/teamwork-on-the-fly-2> [Accessed 10 July 2020]. 
Edmondson, G., Valigra, L., Kenward, M., Hudson, R. and Belfield, H., 2012. Making industry-university partnerships work: Lessons from successful collaborations. Belgium: Business Innovation Board AISBL.

Eftimoski, D. and Milenkovski, B., 2012. The Knowledge Competitiveness of Macedonian Economy-Comparative Analysis. Journal of Competitiveness, [ejournal] 4(3), pp.122-135. DOI: 10.7441/joc.2012.03.09.

Ferreira Rebelo, M., Silva, R. and Santos, G., 2017. The integration of standardized management systems: managing business risk. International Journal of Quality and Reliability Management, [e-journal] 34(3), pp.395-405. DOI: 10.1108/IJQRM-11-2014-0170.

Frølund, L., Murray, F. and Riedel, M., 2018. Developing Successful Strategic Partnerships With Universities Developing Successful Strategic Partnerships With Universities. MIT Sloan Management Review. [online] Available at: $<$ https://sloanreview.mit.edu/article/developing-successful-strategic-partnershipswith-universities/> [Accessed 10 July 2020].

Frow, P., Nenonen, S., Payne, A. and Storbacka, K., 2015. Managing Cocreation: A Strategic Approach to Innovation. British Journal of Management, [e-journal] 26(3), pp.463-483. DOI: 10.1111/1467-8551.12087.

Ghadimi, P., Ghassemi Toosi, F. and Heavey, C., 2018. A multi-agent systems approach for sustainable supplier selection and order allocation in a partnership supply chain. European Journal of Operational Research, [e-journal] 269(1), pp.286-301. DOI: 10.1016/j.ejor.2017.07.014.

Giesecke, J., 2012. The Value of Partnerships: Building New Partnerships for Success. Journal of Library Administration, [e-journal] 52(1), pp.36-52. DOI: 10.1080/01930826.2012.629964.

Grimpe, C., Goel, R. and Göktepe-Hultén, D., 2017. Who instigates university industry collaborations? University scientists versus firm employees. Small Business Economics, [e-journal] 48(3), pp.503-524. DOI: 10.1007/s11187-0169795-9.

Guan, J. and Zhao, Q., 2013. The impact of university-industry collaboration networks on innovation in nanobiopharmaceuticals. Technological Forecasting and Social Change, [e-journal] 80(7), pp.1271-1286. DOI: 10.1016/j.techfore.2012.11.013.

Hartman, L.P. and Dhanda, K.K., 2018. Cross-Sector Partnerships: An Examination of Success Factors. Business and Society Review, [e-journal] 123(1), pp.181-214. DOI: 10.1111/basr.12139.

Hewitt-Dundas, N., Gkypali, A. and Roper, S., 2019. Does learning from prior collaboration help firms to overcome the "two-worlds" paradox in universitybusiness collaboration?. Research Policy, [e-journal] 48(5), pp.1310-1322. DOI: 10.1016/j.respol.2019.01.016. 
Huang, Y. and Wilkinson, I., 2014. A case study of the development of trust in a business relation: Implications for a dynamic theory of trust. Journal of Business Market Management, 7(1), pp.254-279.

Champenois, C. and Etzkowitz, H., 2018. From boundary line to boundary space: The creation of hybrid organizations as a Triple Helix micro-foundation. Technovation, [e-journal] 76-77, pp.28-39. DOI: 10.1016/j.technovation.2017.11.002.

Chi, M., Wang, W., Lu, X. and George, J.F., 2018. Antecedents and outcomes of collaborative innovation capabilities on the platform collaboration environment. International Journal of Information Management, [e-journal] 43, pp.273-283. DOI: 10.1016/j.ijinfomgt.2018.08.007.

Jarábková, J., Chreneková, M. and Roháčiková, O., 2019. University and practice - cooperation in research and science: case study of the slovak university of agriculture in Nitra. Quality Innovation Prosperity, [e-journal] 23(1), pp.136154. DOI: 10.12776/QIP.V23I1.1168.

Johnston, A. and Huggins, R., 2016. Drivers of University-Industry Links: The Case of Knowledge-Intensive Business Service Firms in Rural Locations. Regional Studies, [e-journal] 50(8), pp.1330-1345. DOI: 10.1080/00343404.2015.1009028.

Jonkers, K., Tijssen, R., Karvounaraki, A. and Goenaga Beldarrain, X., 2018. A Regional Innovation Impact Assessment Framework for universities. [pdf] Publications Office of the European Union. Available at: $<$ https://ec.europa.eu/jrc/en/publication/eur-scientific-and-technical-researchreports/regional-innovation-impact-assessment-framework-universities> [Accessed 10 July 2020].

Jørgensen, F. and Ulhøi, J., 2010. Enhancing innovation capacity in SMEs through early network relationships. Creativity and Innovation Management, [ejournal] 19(4), pp.397-404. DOI: 10.1111/j.1467-8691.2010.00577.x.

Konsti-Laakso, S., Pihkala, T. and Kraus, S., 2012. Facilitating SME innovation capability through business networking. Creativity and Innovation, [e-journal] 21(1), pp.93-105. DOI: 10.1111/j.1467-8691.2011.00623.x.

Le Roy, F., Robert, M. and Lasch, F., 2016. Choosing the Best Partner for Product Innovation. International Studies of Management and Organization, [ejournal] 46(2-3), pp.136-158. DOI: 10.1080/00208825.2016.1112148.

Liao, S.-H., Hu, D.-Ch. and Ding, L.-W., 2017. Assessing the influence of supply chain collaboration value innovation, supply chain capability and competitive advantage in Taiwan's networking communication industry. International Journal of Production Economics, [e-journal] 191, pp.143-153. DOI: 10.1016/j.ijpe.2017.06.001. 
Lin, J.-Y., 2017. Balancing industry collaboration and academic innovation: The contingent role of collaboration-specific attributes. Technological Forecasting \& Social Change, [e-journal] 123, pp.216-228. DOI: 10.1016/j.techfore.2016.03.016.

Merritt, C.C. and Kelley, D.C., 2018. What individual and organizational competencies facilitate effective collaboration? Findings from a collaborative governance simulation. Journal of Public Affairs Education, [e-journal] 24(1), pp.97-121. DOI: 10.1080/15236803.2018.1429812.

Mindruta, D., Moeen, M. and Agarwal, R., 2016. A Two-sided Matching Approach for Partner Selection and Assessing Complementarities in Partners' Attributes in Inter-firm Alliances. Strategic Management Journal, [e-journal] 37(1), pp.206-231. DOI: 10.1002/smj.2448.

Nguyen, N. and Liem, N., 2013. Inter-firm trust production: Theoretical perspectives. International Journal of Business and Management, [e-journal] 8(7), pp.46-54. DOI: 10.5539/ijbm.v8n7p46.

Orviská, M., Huňady, J., Pisár, P. and Hudson, J., 2019. From academic publications and patents to the technological development of the economy: Short and long run causalities. Quality Innovation Prosperity, [e-journal] 23(1), pp.74101. DOI: 10.12776/QIP.V23I1.1166.

Pal'ová, D., Czaja, A. and Vejačka, M., 2018. Innovative approach to education improvement via enterprise-education collaboration. Quality Innovation Prosperity, [e-journal] 22(3), pp.68-82. DOI: 10.12776/QIP.V22I3.1171.

Perkmann, M. and Salter, A., 2012. How to Create Productive Partnerships With Universities. MIT Sloan Management Reviews, [online] Available at: $<$ https://sloanreview.mit.edu/article/how-to-create-productive-partnerships-withuniversities/> [Accessed 10 July 2020].

Perkmann, M. and Schildt, H., 2015. Open data partnerships between firms and universities: The role of boundary organizations. Research Policy, [e-journal] 44(5), pp.1133-1143. DOI: 10.1016/j.respol.2014.12.006.

Piacentini, A., 2013. The University - Industry Partnership. A new format to promote innovation. Australia: Government of South Australia.

Plewa, C., Korff, N., Johnson, C., Macpherson, G., Baaken, T. and Rampersad, G., 2013. The evolution of university-industry linkages-A framework. Journal of Engineering and Technology Management, [e-journal] 30(1), pp.21-44. DOI: 10.1016/j.jengtecman.2012.11.005.

Rajalo, S. and Vadi, M., 2017. University-industry innovation collaboration: Reconceptualization. Technovation, [e-journal] 62-63, pp.42-54. DOI: 10.1016/J.TECHNOVATION.2017.04.003. 
Ranga, M. and Etzkowitz, H., 2013. Triple Helix systems: an analytical framework for innovation policy and practice in the Knowledge Society, Industry and Higher Education. Industry and Higher Education, [e-journal] 27(4), pp.237262. DOI: $10.5367 /$ ihe.2013.0165.

Ranga, M., Hoareau, C., Durazzi, N., Etzkowitz, H., Marcucci, P. and Usher, A., 2013. Study on university-business cooperation in the US. London: LSE Enterprise.

Rebelo, M.F., Santos, G. and Silva, R., 2015. Integration of management systems: Towards a sustained success and development of organizations. Journal of Cleaner Production, [e-journal] 127, pp.99-111. DOI: 10.1016/j.jclepro.2016.04.011.

Reficco, E., Gutiérrez, R., Jaén, M.H. and Auletta, N., 2018. Collaboration mechanisms for sustainable innovation. Journal of Cleaner Production, [ejournal] 203, pp.1170-1186. DOI: 10.1016/j.jclepro.2018.08.043.

Rehák, Š., Šipikal, M. and Lešková, A., 2019. Evolution of university third mission activities in slovakia: What role for a public policy?. Quality Innovation Prosperity, [e-journal] 23(1), pp.119-135. DOI: 10.12776/QIP.V23I1.1165.

Reichert, S., 2019. The Role of Universities in Regional Innovation Ecosystems. Geneva: European University Association.

Resetarits, A. and Resetarits-Tincul, A.-M., 2012. Fuzzy Concepts-A New Approach in the Description of Boundaries as Creative Knowledge Environments in Educational Sciences. Journal of the Knowledge Economy, [e-journal] 3(1), pp.53-67. DOI: 10.1007/s13132-011-0050-y.

Roud, V. and Vlasova, V., 2018. Strategies of industry - science cooperation in the Russian manufacturing sector. The Journal of Technology Transfer, [ejournal] 45(3), pp.870-907. DOI: 10.1007/s10961-018-9703-3.

Santos, G., Murmura, F. and Bravi, L., 2019. Developing a model of vendor rating to manage quality in the supply chain. International Journal of Quality and Service Sciences, [e-journal] 11(1), pp.34-52. DOI:10.1108/IJQSS-06-20170058.

Schilke, O. and Cook, K., 2013. A cross-level process theory of trust development in interorganizational relationships. Strategic Organization, [ejournal] 11(3), pp.281-303. DOI: 10.1177/1476127012472096.

Smirnova, M.M., Rebiazina, V.A. and Khomich, S.G., 2018. When does innovation collaboration pay off ? The role of relational learning and the timing of collaboration. Industrial Marketing Management, [e-journal] 74, pp.126-137. DOI: 10.1016/j.indmarman.2017.11.001. 
Sum Chau, V., Gilman, M. and Serbanica, C., 2016. Aligning UniversityIndustry Interactions: the Role of Boundary Spanning in Intellectual Capital Transfer.Technological Forecasting and Social Change. Kent Academic Repository, [e-journal] 123, pp.199-209. DOI: 10.1093/bjc/azq038.

Thune, T. and Gulbrandsen, M., 2014. Dynamics of collaboration in universityindustry partnerships: do initial conditions explain development patterns?. Journal of Technology Transfer, [e-journal] 39(6), pp.977-993. DOI: 10.1007/s10961-014-9331-5.

Un, C.A. and Rodríguez, A., 2018. Local and Global Knowledge Complementarity: R \& D Collaborations and Innovation of Foreign and Domestic Firms. Journal of International Management, [e-journal] 24(2), pp.137-152. DOI: 10.1016/j.intman.2017.09.001.

Unger, M., Marsan, G.A., Meissner, D., Polt, W. and Cervantes, M., 2018. New challenges for universities in the knowledge triangle. The Journal of Technology Transfer, [e-journal] 45, pp.806-819. DOI: 10.1007/s10961-018-9699-8.

Veles, N., Carter, M.-A. and Boon, H., 2018. Complex collaboration champions: university third space professionals working together across borders. Perspectives: Policy and Practice in Higher Education, [e-journal] 23(2-3), pp.111. DOI: 10.1080/13603108.2018.1428694.

Wu, I.L. and Chiu, M.L., 2015. Organizational applications of IT innovation and firm's competitive performance: A resource-based view and the innovation diffusion approach. Journal of Engineering and Technology Management, [ejournal] 35, pp.25-44. DOI: 10.1016/j.jengtecman.2014.09.002.

Yoon, C., Lee, K., Yoon, B. and Toulan, O., 2017. Typology and success factors of collaboration for sustainable growth in the IT service industry. Sustainability, [e-journal] 9(11), pp.1-20. DOI: 10.3390/su9112017.

\section{ABOUT AUTHORS}

Arlindo Marinho - (A.M.) Universidade Lusíada - Norte, Portugal, Ph.D. Student, e-mail: arlindo_marinho@hotmail.com, Author's ORCID: 0000-00033668-9914.

Rui G. Silva - (R.G.S.) Universidade Lusíada - Norte, Portugal, Engineering and Technology Faculty, Assoc. Prof., e-mail: rgasilva@gmail.com, Author's ORCID: 0000-0002-7929-0367.

Gilberto Santos - (G.S.) Polytechnic Institute Cávado Ave (IPCA), Barcelos, Portugal, Prof., e-mail: gsantos@ipca.pt, Author's ORCID: 0000-0001-92683272. 


\section{AUTHOR CONTRIBUTIONS}

A.M. - conceptualization, investigation, writing - original draft; R.G.S., G.S. supervision; A.M., R.G.S., G.S. - methodology, writing - review \& editing.

\section{CONFLICTS OF INTEREST}

The authors declare no conflict of interest. The funders had no role in the design of the study; in the collection, analyses, or interpretation of data; in the writing of the manuscript, or in the decision to publish the results.

(C) 2020 by the authors. Submitted for possible open access publication under the terms and conditions of the Creative Commons Attribution (CC-BY) license (http://creativecommons.org/licenses/by/4.0/). 